\title{
Can peripheral blood be used as surrogate in detecting epidermal growth factor receptor mutation status in advanced non-small cell lung cancer patients? A meta-analysis
}

\author{
Xiaowei Mao ${ }^{1}$, Yujun Zhang ${ }^{1}$, Fangfang Xie ${ }^{1}$, Xiaoxuan Zheng ${ }^{1}$ and Jiayuan Sun ${ }^{1}$ \\ ${ }^{1}$ Department of Endoscopy and Pulmonary Medicine, Shanghai Chest Hospital, Shanghai Jiao Tong University, Shanghai \\ 200030, PR China \\ Correspondence to: Jiayuan Sun, email: xkyyjysun@163.com \\ Keywords: EGFR, peripheral blood, advanced NSCLC, mutation, meta-analysis \\ Received: December 28, $2016 \quad$ Accepted: June 01, $2017 \quad$ Published: August 16, 2017 \\ Copyright: Mao et al. This is an open-access article distributed under the terms of the Creative Commons Attribution License 3.0 \\ (CC BY 3.0), which permits unrestricted use, distribution, and reproduction in any medium, provided the original author and source \\ are credited.
}

\section{ABSTRACT}

Background: Apply peripheral blood as a surrogate for detecting epidermal growth factor receptor mutation status in tumor, also called liquid biopsy, has been reported to be a feasible method in patients with advanced non-small lung cancer. But the diagnostic yield varies in different studies.

Methods: A meta-analysis was carried out to evaluate the sensitivity and specificity of peripheral blood in detection epidermal growth factor receptor mutation status in advanced non-small lung cancer patients. Publications up to October 2016 were searched using PubMed, Embase and Web of Science databases. Sensitivity, specificity and other parameters were pooled using the bivariate mixed-effects regression model.

Results: Fifteen studies meeting the inclusion criteria were included. The pooled sensitivity, specificity, positive likelihood ratio, negative likelihood ratio and diagnostic odds ratio were 0.69 (95\% CI: 0.59 0.78), 0.97 (95\% CI: 0.94 0.99), 23.1 (95\% CI: 11.6 46.1), 0.32 (95\% CI: $0.23 \sim 0.44), 73$ (95\% CI: 33 159), respectively. The summary receiver operating characteristic curve was 0.93 (95\% CI: $0.91-0.95$ ).

Discussion: Detecting epidermal growth factor receptor mutation in peripheral blood is a reliable and non-invasive method in patients with advanced non-small lung cancer. More sensitive detection methods are required to increase the sensitivity of liquid biopsy of ctDNA.

\section{INTRODUCTION}

Lung cancer is the leading cause of cancer-related death worldwide and non-small cell lung cancer (NSCLC) is the major type [1-2]. Since most patients with NSCLC are diagnosed at an advanced stage, when curative procedures are not available [3]. In addition, platinumbased doublet chemotherapy has reaches its plateau [4]. Several prospective clinical studies on EGFR inhibitors have demonstrated their efficacies and less toxicity in patients harboring epidermal growth factor receptor (EGFR) activating mutations [5-8]. Exon 19 deletion and substitution of $\mathrm{L}$ with $\mathrm{R}$ at position 858 in exon 21 have accounted for the majority of the EGFR mutations
[9]. NCCN guidelines suggest to test for EGFR status in advanced NSCLC (aNSCLC) prior to commencing EGFR-TKIs as the first-line therapy [10].

Nowadays, tissue biopsies are still regarded as the golden standard for EGFR mutation examination. However, tissue biopsy has limited ability in reflecting tumor heterogeneity, owning to its spatial and temporal snapshot nature. Furthermore, tissue biopsy is also invasive and occasionally would result in complication. Tissue biopsy can't apply to a significant fraction of advanced patients with prior treatments [11]. Liquid biopsy, containing ctDNA released from apoptotic or necrotic tumor cells, can potentially reflect the genetic profile of tumors [12-14]. Numerous studies have shown 
that EGFR status can be detected using ctDNA. However, the sensitivity of using different assays assessing EGFR status from ctDNA varies significantly, ranging from $22 \%$ to $94 \%$ [15-16].

In this study, we reviewed 15 manuscripts to investigate whether the peripheral blood can be used as a reliable surrogate specimen for detecting EGFR mutation status in aNSCLC patients when the tumor tissue is unavailable or inadequate.

\section{RESULTS}

\section{Study selection}

Our search strategy identified 278 publications for consideration. Of these, 29 duplicated studies and 37 reviews were eliminated. Then, 169 were excluded based on review of the titles and abstracts. Of the 43 publications remained, full articles were obtained and reviewed, and another 28 studies were excluded for the following reasons: five were repeated articles; two had too little data to form the $2 \times 2$ table; four studies lacked the comparison of EFGR status between blood and tissue; eleven compared pre-treatment tissue and posttreatment blood; and six did not specifically pertain to the subject. (Figure 1) Fifteen publications meeting all of the inclusion criteria were considered for the metaanalysis.

\section{Study descriptions and quality assessment}

The characteristics of the included studies are listed in Table 1. A total of 2094 patients were enrolled, ranging from 32 to 652 patients per study. Of all studies, six studies were prospective, two studies were retrospective, and the remaining seven studies did not specify the study type. Thirteen studies enrolled Asian patients and the other two only enrolled Caucasians. Twelve studies detected EGFR mutations using plasma, two studies used serum, and one study used ctDNA extracted from specimen combinated with plasma and serum. The amount of blood needed in eight studies is less than $6 \mathrm{ml}$, in 3 studies is more than $6 \mathrm{ml}$, and 4 studies didn't specify. The same detection method was applied in eleven studies and different detection methods were applied in the remaining four studies.

QUADAS-2 summary plot was presented in Supplementary Figure 1. The pooled sensitivity was 0.69 (95\% confidence interval (CI): 0.59-0.78), and specificity was 0.97 (95\% CI: 0.94-0.99). The results showed a positive likelihood ratio (PLR) of 23.1 (95\% CI: 11.6-46.1) and a negative likelihood ratio (NLR) of 0.32 (95\% CI: $0.23-0.44)$. The diagnostic odds ratio (DOR) was 73 (95\%CI: 33-159), and the area under the curve (AUC) was 0.93 (95\%CI: 0.91-0.95), showing that EGFR mutation detection in peripheral blood had a high diagnostic performance. The detailed sensitivity and specificity with $95 \%$ CI for each study are presented in a Forest plot. (Figure 2, Figure 3)

\section{Heterogeneity assessment and meta-regression analysis}

The $\mathrm{P}$ value for the Spearman correlation coefficient was 0.09 , confirming that the threshold-effect was not significant. The meta-regression analysis showed that the detection method applied in two specimens is the most important source of heterogeneity $(\mathrm{P}<0.05)$. (Table 2$)$

\section{Subgroup analysis}

The subgroup with same method applied in both blood and tumor tissue had a poor pooled sensitivity $(0.64,95 \%$ CI: $0.53-0.75)$ than the subgroup with different methods applied in two specimen $(0.81,95 \% \mathrm{CI}: 0.68-0.93)(\mathrm{P}=$ 0.02 ). No statistically significant differences were found between the pooled specificities of the studies with same method applied in both specimen (0.98, 95\% CI: 0.97-0.99) and that of the studies with different method applied in both specimen (0.90, 95\% CI: 0.83-0.97) $(\mathrm{P}=0.93)$.

No significant difference was found between the pooled sensitivities and specificities of the studies with ethnicity (Asian versus non-Asian), design (prospective versus retrospective or unspecified), sample type (plasma versus serum or mixed), blood amount $(>6 \mathrm{ml}$ versus $<=6 \mathrm{ml}$ or unspecified). The results of the subgroup analysis are shown in Table 2 and Figure 4.

\section{Publication bias}

As shown in Supplementary Figure 2, the $\mathrm{P}$ value of $0.28(\mathrm{P}>0.05)$ suggested no publication bias observed.

\section{DISCUSSION}

The development of EGFR-TKIs has revolutionized the treatment of NSCLC, benefiting a sub-population of patients harboring EGFR mutations with a median PFS of 12 months. Therefore, obtaining EGFR mutation status prior to commencing EGFR-TKIs is necessary [11]. Although tumor tissue obtained from surgery or biopsy is still regarded as the gold standard; however, it are unwilling to undergo repeat tissue biopsy. Peripheral blood, one of the non-invasive surrogates for driver gene examination, has attracted attention. An increasing number of studies focused on liquid biopsy in NSCLC patients had published in the last few years. However, obtaining EGFR status using peripheral blood for EGFR mutation detection in aNSCLC patients is still far from clear.

In our study, the results revealed that EGFR mutation detection in peripheral blood has high specificity (0.97) and moderate sensitivity (0.69). 
Furthermore, the overall test performance assessed by the AUC was excellent (area under $\mathrm{ROC}=0.93$ ). The results also showed a good overall PLR and NLR values of 23.1 and 0.32 , respectively. The results indicated that if EGFR mutations were detected in the blood of aNSCLC patients, most likely they harbor EGFR mutations in tumor burden.

In our study, we have pooled 15 published studies, including a total of 2094 aNSCLC patients. The AUC of SROC was 0.93 (95\% CI: 0.91-0.95), showed an excellent overall diagnostic yield. In our meta-analysis, the mean DOR of 73 suggested that peripheral blood was reliable in detecting EGFR mutation status in aNSCLC patients. Likelihood ratios are more clinically meaningful than sensitivity or specificity values [30]. In this study, the value of PLR was 23.1, which is high enough for clinical purposes. However, the NLR value was 0.32 , which is not low enough to exclude the EGFR mutation when EGFR detection in blood is negative.

It is important to note that significant heterogeneity exited among the studies analyzed in our work. But there was no threshold effect observed $(\mathrm{p}=0.09)$. Furthermore, we conducted meta-regression analysis to explore the source of heterogeneity. We found that the detection method applied in two specimens is responsible for the heterogeneity. In the subgroup analysis, studies with same detection method applied in two specimens had a poor sensitivity than studies with different detection methods applied. The other subgroups, including race, design, sample types or blood amount don't show significantly different sensitivities or specificities.

The level of ctDNA in healthy controls is low, but it is significantly increased in NSCLC patients, especially those patients with advanced disease [12].

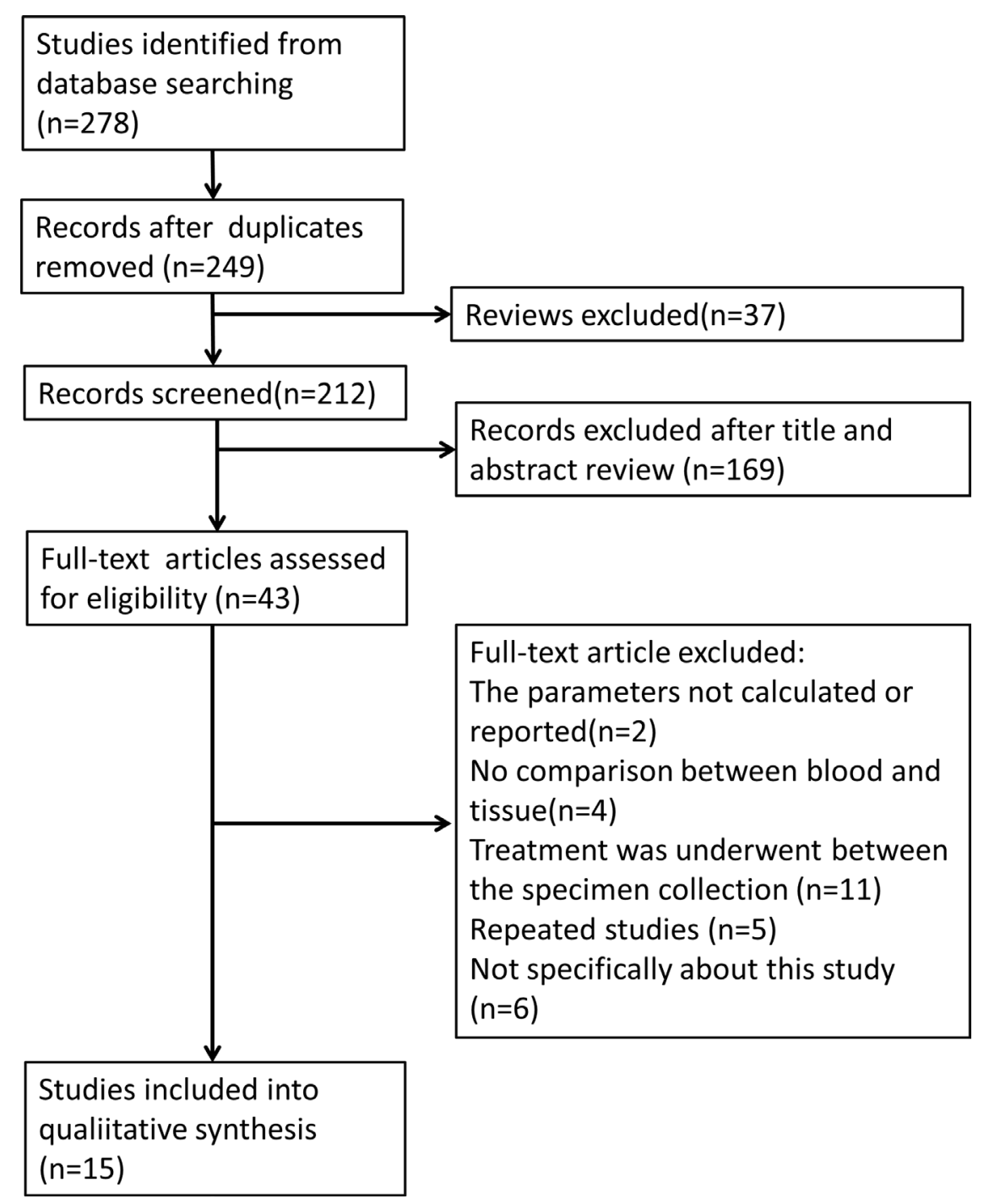

Figure 1: Flow chart for articles identified and included in this meta-analysis. 
Table 1: Characteristics of eligible studies

\begin{tabular}{|c|c|c|c|c|c|c|c|c|c|}
\hline $\begin{array}{l}\text { First } \\
\text { Author }\end{array}$ & Ethnicity & Design & $\begin{array}{c}\text { Blood } \\
\text { Sample }\end{array}$ & $\begin{array}{c}\text { Blood } \\
\text { Amount }\end{array}$ & Stage & $\begin{array}{c}\text { Method } \\
\text { (tissue) }\end{array}$ & $\begin{array}{c}\text { Method } \\
\text { (blood) }\end{array}$ & type & $\begin{array}{c}\text { No. of } \\
\text { Patients }\end{array}$ \\
\hline $\begin{array}{l}\text { Kimura et } \\
\text { al. [17] }\end{array}$ & Asian & Retrospective & Serum & $4 \mathrm{ml}$ & IIIB-IV & $\begin{array}{c}\text { Direct } \\
\text { sequencing }\end{array}$ & ARMS & $\begin{array}{c}\mathrm{ADC}, \mathrm{SQCC} \\
\mathrm{LCC}\end{array}$ & 42 \\
\hline $\begin{array}{l}\text { Bai et al. } \\
{[18]}\end{array}$ & Asian & Prospective & Plasma & NA & IIIB-IV & DHPLC & DHPLC & $\begin{array}{c}\mathrm{ADC}, \mathrm{SQCC} \\
\mathrm{LCC}\end{array}$ & 230 \\
\hline $\begin{array}{l}\text { Yung et al. } \\
{[16]}\end{array}$ & Asian & Prospective & Plasma & $2-6$ & III-IV & $\mathrm{dPCR}$ & dPCR & NSCLC & 32 \\
\hline $\begin{array}{l}\text { Jiang et al. } \\
\text { [19] }\end{array}$ & Asian & NA & Serum & $5 \mathrm{ml}$ & IIIB-IV & ME-PCR & ME-PCR & $\begin{array}{c}\mathrm{ADC}, \mathrm{SQCC} \\
\mathrm{LCC}\end{array}$ & 58 \\
\hline $\begin{array}{l}\text { Xu et al. } \\
{[20]}\end{array}$ & Asian & Retrospective & Plasma & NA & IIIB-IV & ARMS & ARMS & NSCLC & 34 \\
\hline $\begin{array}{l}\text { Zhang et } \\
\text { al. [21] }\end{array}$ & Asian & NA & Plasma & $5 \mathrm{ml}$ & IIIB-IV & $\begin{array}{c}\text { mutant } \\
\text { enriched } \\
\text { liquidchip }\end{array}$ & $\begin{array}{c}\text { mutant } \\
\text { enriched } \\
\text { liquidchip }\end{array}$ & NSCLC & 86 \\
\hline $\begin{array}{l}\text { Kim et al. } \\
{[22]}\end{array}$ & Asian & Prospective & Plasma & $6 \mathrm{ml}$ & IIIB-IV & $\begin{array}{c}\text { Direct } \\
\text { sequencing }\end{array}$ & PNA-PCR & ADC, SQCC & 57 \\
\hline $\begin{array}{l}\text { Wang et al. } \\
{[16]}\end{array}$ & Asian & Prospective & Plasma & $2 \mathrm{ml}$ & IIIB-IV & ARMS & ARMS & NSCLC & 134 \\
\hline $\begin{array}{l}\text { Li et al. } \\
{[23]}\end{array}$ & Asian & NA & Plasma & $4 \mathrm{ml}$ & IIIB-IV & SARMS & SARMS & NSCLC & 121 \\
\hline $\begin{array}{l}\text { Douillard } \\
\text { et al. [24] }\end{array}$ & Caucasian & Prospective & Plasma & NA & III, IV & SARMS & SARMS & NSCLC & 652 \\
\hline $\begin{array}{l}\text { Zhu et al. } \\
{[25]}\end{array}$ & Asian & NA & Plasma & NA & IIIB-IV & ARMS & ddPCR & $\begin{array}{c}\text { ADC, } \\
\text { ADSQC }\end{array}$ & 86 \\
\hline $\begin{array}{l}\text { Mok et al. } \\
{[26]}\end{array}$ & Asian & Prospective & NA & 2 & IIIB-IV & $\begin{array}{c}\text { allele-specific } \\
\text { PCR }\end{array}$ & $\begin{array}{c}\text { allele-specific } \\
\text { PCR }\end{array}$ & NSCLC & 238 \\
\hline $\begin{array}{l}\text { Rachiglio } \\
\text { et al. [27] }\end{array}$ & Caucasian & NA & Plasma & 10 & III-IV & NGS & NGS & NSCLC & 44 \\
\hline $\begin{array}{l}\text { Ma et al. } \\
{[28]}\end{array}$ & Asian & NA & Plasma & 20 & III-IV & ARMS & ARMS & NSCLC & 219 \\
\hline $\begin{array}{l}\text { Chai et al. } \\
\text { [29] }\end{array}$ & Asian & NA & Plasma & 10 & III, IV & ARMS & cSMART & ADC, SQCC & 61 \\
\hline
\end{tabular}

NA: not mention; ARMS: amplification refractory mutation system; DHPLC: denaturing high performance liquid chromatography; ddPCR: droplet digital PCR; ME-PCR: mutant-enriched polymerase chain reaction; SARMS: scorpions amplification refractory mutation system; NGS: next-generation sequencing; cSMART: circulating single-molecule amplification and re-sequencing technology; ADC: adenocarcinoma; SQCC: squamous carcinoma; LCC: large cell carcinoma; NSCLC: non-small cell lung cancer.

Although the source of ctDNA is still not clear, many studies indicated that necrosis or apoptosis of tumor cells were the main source of the DNA fragment found in peripheral blood of cancer patients. In addition, the lysis of circulating tumor cells (CTCs) and the secretion of DNA fragment by the tumor cells also result in the increased level of ctDNA [31-33]. Jose et.al reported their successful attempt in detecting KRAS mutation in NSCLC patients with a good diagnostic yield of 0.74 [34]. Kimura et.al first reported their study of detecting EGFR mutation in serum with direct sequencing technique and obtained a moderate diagnostic yield of 0.55 [35]. However, the diagnostic yield increased to 0.73 if the scorpions amplification refractory mutation system (sARMS) technique was applied to the same cohort [36]. Interestingly, some studies also indicated that the sensitivity was associated with tumor differentiation [37].

Numerous methods were applied in liquid biopsy including mutant-enriched PCR (ME-PCR), denaturing high-performance liquid chromatography (DHPLC), high resolution melting (HRM), droplet digital PCR (ddPCR), next-generation sequencing, etc., but the sensitivity and diagnostic yield varied, partially attributing to the 


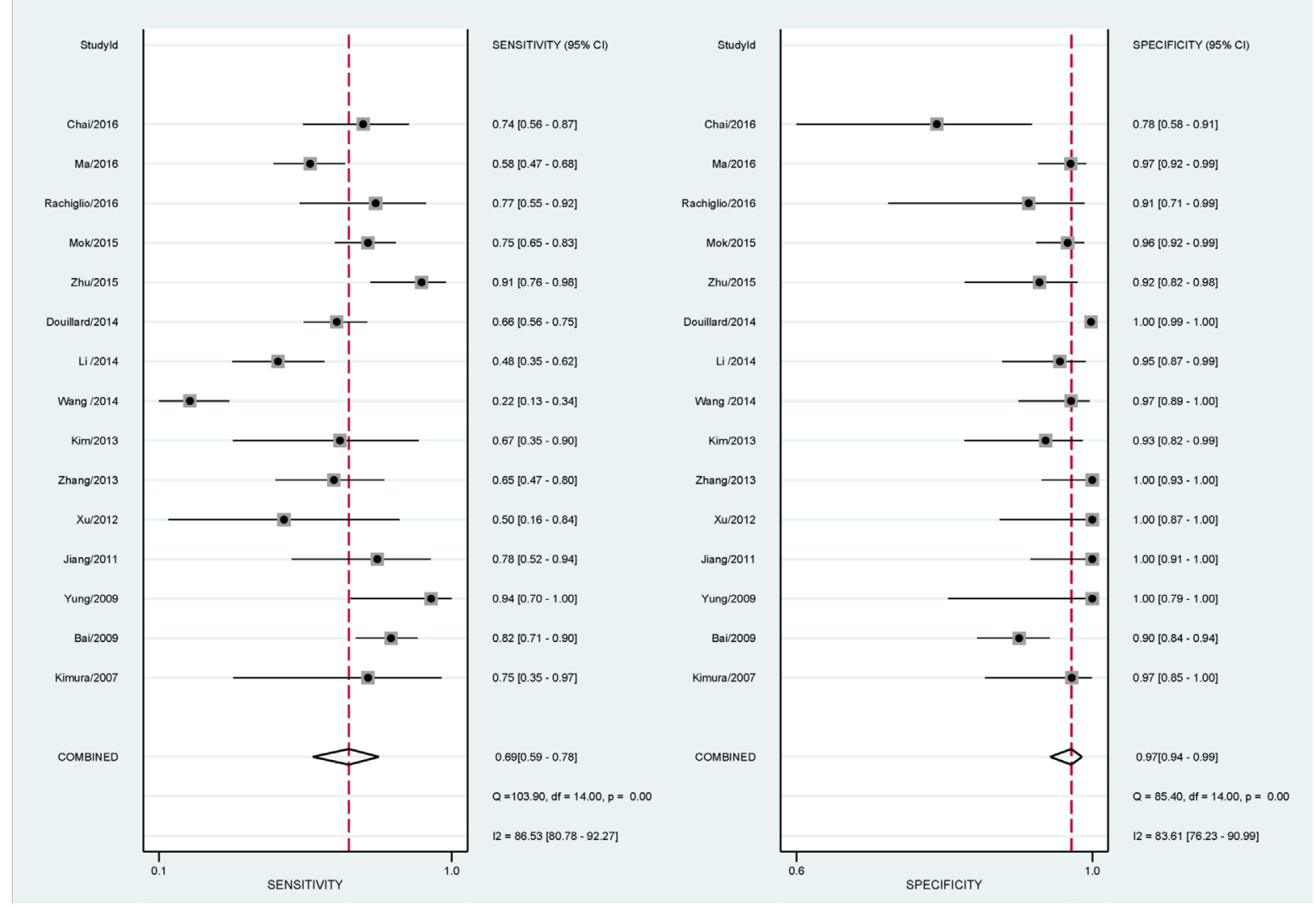

Figure 2: Forest plots of pooled sensitivity and specificity. The plots showed the pooled sensitivity was 0.66 (95\% confidence interval (CI): 0.54-0.77), and the specificity was 0.97 (95\% CI: 0.94-0.99) of liquid biopsy in advanced non-small cell lung cancer patients.
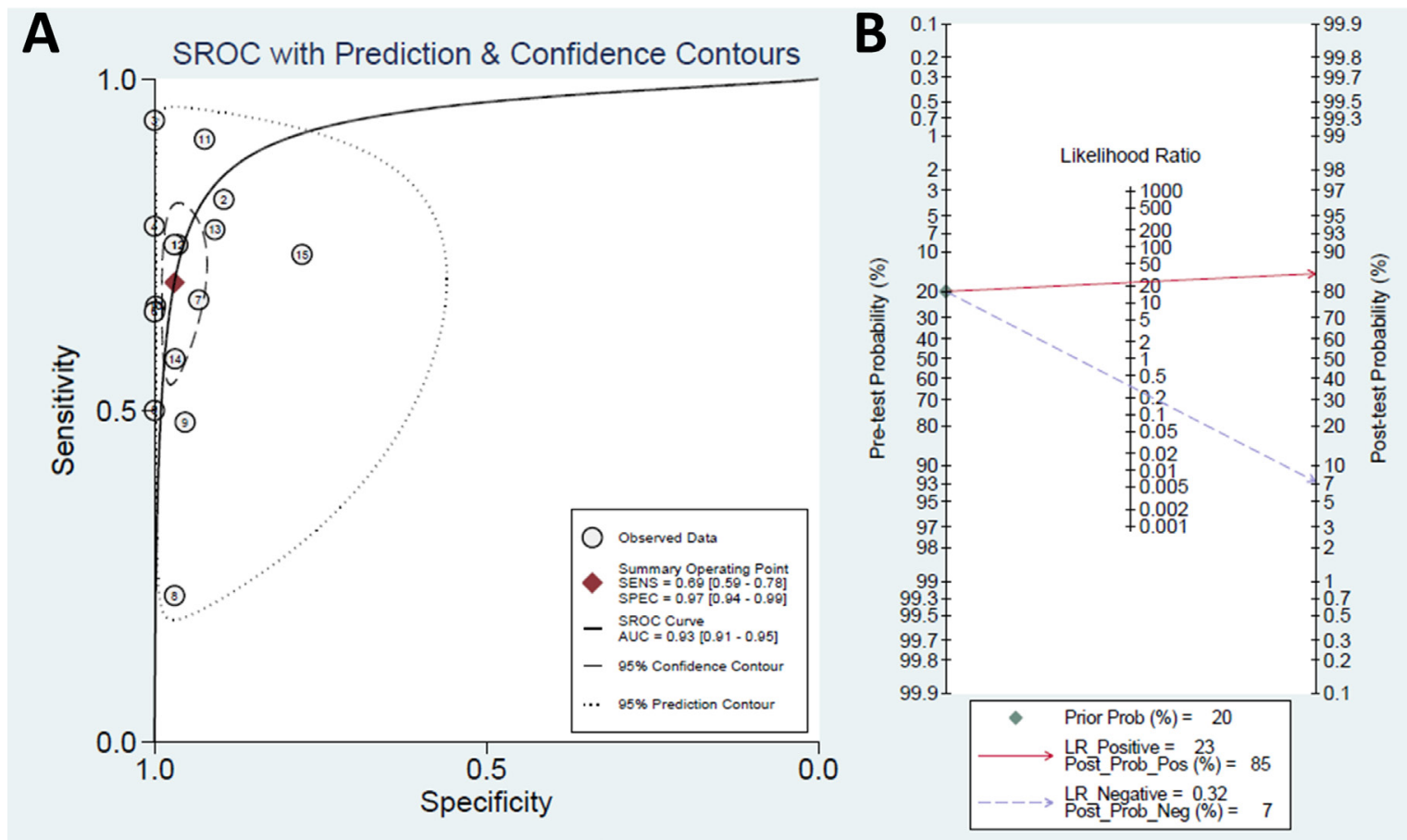

Figure 3: (A) Summary receiver operating characteristics (SROC) plot. It showed a good performance of liquid biopsy in advanced nonsmall cell lung cancer patients. (B) Fagan plot of the positive likelihood ratio and negative likelihood ratio. The plot showed a good positive likelihood ratio and a moderate negative likelihood ratio. 
Table 2: Subgroup analysis

\begin{tabular}{|c|c|c|c|c|c|}
\hline Subgroup & No. of studies & $\begin{array}{c}\text { Summary } \\
\text { sensitivity }(95 \% \\
\text { CI) }\end{array}$ & $\mathbf{p}$ & $\begin{array}{l}\text { Summary specificity } \\
(95 \% \mathrm{CI})\end{array}$ & $\mathbf{P}$ \\
\hline Ethnicity & & & 0.50 & & 0.17 \\
\hline Asia & 13 & $0.69[0.58-0.79]$ & & $0.96[0.94-0.99]$ & \\
\hline Non-Asia & 2 & $0.73[0.49-0.97]$ & & $0.99[0.97-1.00]$ & \\
\hline Design & & & 0.33 & & 0.31 \\
\hline Prospective & 6 & $0.69[0.53-0.84]$ & & $0.97[0.95-1.00]$ & \\
\hline Retrospective or NA & 9 & $0.70[0.57-0.83]$ & & $0.97[0.93-1.00]$ & \\
\hline Sample & & & 0.08 & & 0.76 \\
\hline Plasma & 12 & $0.66[0.55-0.77]$ & & $0.97[0.95-0.99]$ & \\
\hline Serum or NA & 3 & $0.79[0.63-0.94]$ & & $0.96[0.91-1.00]$ & \\
\hline Same detection Methods & & & 0.02 & & 0.93 \\
\hline No & 4 & $0.81[0.68-0.93]$ & & $0.90[0.83-0.97]$ & \\
\hline Yes & 11 & $0.64[0.53-0.75]$ & & $0.98[0.97-0.99]$ & \\
\hline Blood & & & 0.51 & & 0.54 \\
\hline$>6 \mathrm{ml}$ & 3 & $0.70[0.49-0.91]$ & & $0.92[0.82-1.00]$ & \\
\hline$\leq 6 \mathrm{ml}$ or $\mathrm{NA}$ & 12 & $0.69[0.58-0.80]$ & & $0.98[0.96-0.99]$ & \\
\hline
\end{tabular}

differential detection limit of each method. Method with low sensitivity would fail to detect mutations with low allelic frequency [38]. In addition, as the different inclusion criteria were adopted, some studies suggested that the sensitivity of liquid biopsy in early-stage patients is lower than those with aNSCLC [37, 39]. In Song's study, they even failed to detect EGFR mutations in patients with early-stage NSCLC utilizing direct sequencing technique [40]. However, several metaanalysis demonstrated that the stage of enrolled patients or the methods applied in liquid biopsy didn't influence the sensitivity and specificity [41-43]. In our study, we found that the pooled sensitivity is poor in the group utilized the same detection method.

In $\mathrm{Wu}$, Luo and Mao's studies, they included the studies with different stages. In our study, only studies with aNSCLC were selected [41-43]. For most patients with early-stage NSCLC, they can benefit from surgery and the tumor tissue is adequate for genetic profiling. Advanced NSCLC patients are not candidates for surgery. They often undergo target therapy if they harbor sensitized driver gene mutations. However, about one out of three patients with aNSCLC would fail to undergo driver gene testing even in well-designed clinical trials [44-45]. Although fewer studies were selected in our study, the results were more clinically relevant than the previous three studies.
There are some limitations associated with this study, which may influence the interpretation of the results of this meta-analysis. This review may suffer from a verification bias. In some studies, they applied plasma for liquid biopsy, but in other studies, serum was used, even in one study, mixed specimen of plasma and serum was used. Several studies suggested that plasma would have a better performance than serum $[23,46]$. But, in our study, no significant difference was found among the studies used plasma and the studies used serum or mixed specimen in the subgroup analysis. In the subgroup analysis, we were unable to find a difference in the diagnostic yield of the prospective studies and those retrospective studies or studies without specified type. Although no publication bias was observed, studies with positive or significant results are more likely to be published; therefore, a certain degree of publication bias must be expected.

In summary, the results of our study revealed that the detection of EGFR mutations in the peripheral blood of aNSCLC patients is a non-invasive and reliable method. Since a high specificity and moderate sensitivity were observed in this study, it is likely to detect EGFR mutations in peripheral blood as a promising surrogate instead of traditional tissue biopsies. However, more well-designed studies are required to identify patients who can benefit from liquid biopsy the most. 


\section{Univariable Meta-regression \& Subgroup Analyses}

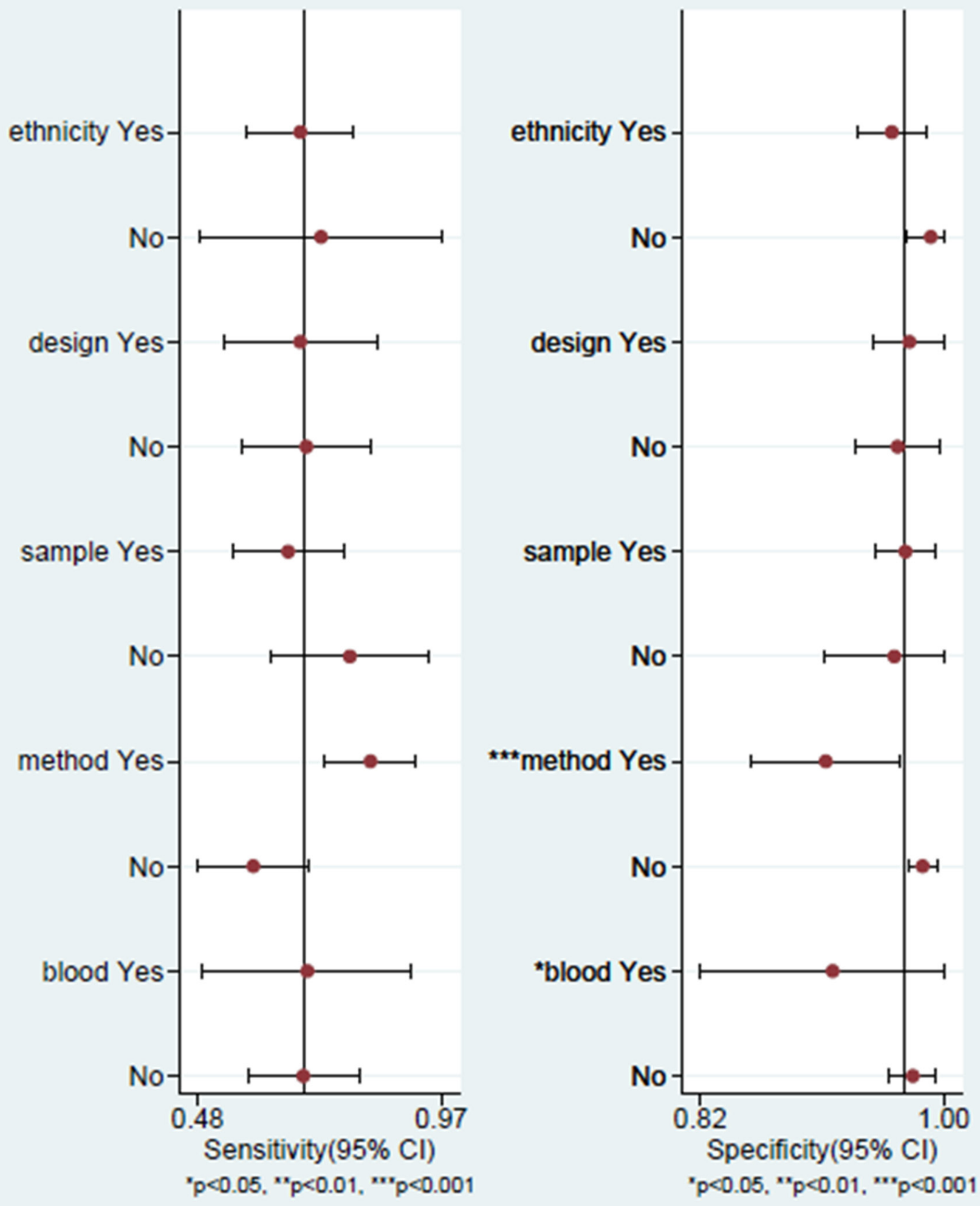

Figure 4: Forest plots of subgroup: analyses for sensitivity and specificity. No significant different were found between the pooled specificities of the studies with ethnicity, design, sample, blood, method. A significant different were found between the pooled sensitivities of the studies with method (same methods in specimens versus different methods in specimens). The other subgroups (ethnicity, design, sample) didn't showed a significant different of sensitivity. 


\section{MATERIALS AND METHODS}

\section{Literature search}

We carried out a computerized search of published research studies in the database of Medline, Embase, Web of Science databases and Cochrane library by using the following key words: "peripheral blood OR plasma OR serum" AND"epidermal growth factor receptor" AND "mutation" AND "non-small cell lung cancer". Alternative spellings and abbreviations were also considered. Reference lists of included studies and relevant reviews were also manually searched. The literature search was conducted without any limitations. Literature published prior to Oct 2016 in English language were considered. Conference abstracts or letters to journal editors were excluded because of their limited data.

\section{Inclusion criteria}

All potentially relevant studies met the following criteria were retrieved and assessed for inclusion: (1) the study must compare EGFR mutation statuses of peripheral blood and tumor tissues; (2) the study should include sufficient data (true-positives, false-positives, true-negatives, and false-negatives) for the calculation of following parameters: sensitivity, specificity, PLR, NLR and DOR; (3) no going treatment (including chemotherapy, radiotherapy, target therapy, etc) between blood collection and tissue collection; (4) all patients included should diagnose with aNSCLC, ranging from IIIA to IV according to the latest TNM stage of lung cancer [47]. If the same study cohort was appeared in several articles, only the latest article was selected. If several methods were applied in one cohort, only the best result was selected. Disagreements were resolved by discussion.

\section{Data extraction}

Data were extracted from all selected studies by two reviewers working independently, using a standardized form to ensure that all relevant information was captured. The following data were extracted from each publication: author, publication year, ethnicity, study design, peripheral blood specimen type (plasma or serum), the amount of peripheral blood required, tumor stage of the patients enrolled, pathological type, method used for EGFR mutation detection in peripheral blood specimen, method used for EGFR mutation detection in tumor tissue, total number of patients enrolled, the distribution of true-positives, false-positives, true-negatives and falsenegatives. Any missing data were treated as "not reported". No minimum number of patients for a study was required to be included in our meta-analysis. Two reviewers assessed the trial methodology of diagnostic studies according to the QUADAS scoring system [48]. The third author assessed the data and resolved the disagreement.

\section{Statistical analysis}

All analysis was conducted according to the standard methods recommended for a meta-analysis of diagnostic test evaluations [49]. All calculations were carried out with the STATA version 12.0 statistical software package (Stata Corp., College Station, TX, USA) with the "midas" program. For each study, we calculated the following five parameters: sensitivity, specificity, PLR, NLR and DOR. All the analysis was based on a summary receiver-operator characteristic (SROC) curve [49-50]. The bivariate regression model was used to calculate the pooled sensitivity, specificity and the other parameters [51]. The likeslihood $\chi^{2}$ test and $\mathrm{I}^{2}$ statistics were used to detect statistically significant heterogeneity across the studies. An $\mathrm{I}^{2}$ value over $50 \%$ was an index of lack of heterogeneity between studies. For the likelihood ratio $\chi^{2}$ test, apparent heterogeneity existed if $\mathrm{P}<0.05$. When heterogeneity was detected, the Spearman correlation coefficient would calculate to judge whether the threshold effect existed or not. Then meta-regression and subgroup was done to explore other sources of between-study heterogeneity. Covariates included ethnicity (Asian or non-Asian), the study design (prospective or not), sample (plasma or not), the amount of peripheral blood (if more than $6 \mathrm{ml}$ ), method applied in peripheral blood and tumor tissue (same or not). The potential publication bias was estimated by Deeks' funnel plots [52].It was considered a statistically significant publication bias existed if the $\mathrm{P}$ value is less than 0.1 .

\section{CONFLICTS OF INTERESTS}

The authors declare no conflicts of interest.

\section{REFERENCES}

1. Siegel RL, Miller KD, Jemal A. Cancer statistics, 2016. CA Cancer J Clin. 2016; 66:7-30.

2. Chen W, Zheng R, Baade PD, Zhang S, Zeng H, Bray F, Jemal A, Yu XQ, He J. Cancer statistics in China, 2015. CA Cancer J Clin. 2016; 66:115-132.

3. Mitsudomi T, Suda K, Yatabe Y. Surgery for NSCLC in the era of personalized medicine. Nat Rev Clin Oncol. 2013; 10:235-244.

4. Reungwetwattana T, Eadens MJ, Molina JR. Chemotherapy for non-small-cell lung carcinoma: from a blanket approach to individual therapy. Semin Respir Crit Care Med. 2011; 32:78-93.

5. Mok TS, Wu YL, Thongprasert S, Yang CH, Chu DT, Saijo N, Sunpaweravong P, Han B, Margono B, Ichinose Y, Nishiwaki Y, Ohe Y, Yang JJ, et al. Gefitinib or carboplatinpaclitaxel in pulmonary adenocarcinoma. N Engl J Med. 2009; 361:947-957.

6. Zhou C, Wu YL, Chen G, Feng J, Liu XQ, Wang C, Zhang S, Wang J, Zhou S, Ren S, Lu S, Zhang L, Hu C, et al. 
Erlotinib versus chemotherapy as first-line treatment for patients with advanced EGFR mutation-positive non-smallcell lung cancer (OPTIMAL, CTONG-0802): a multicentre, open-label, randomised, phase 3 study. Lancet Oncol. 2011; 12:735-742.

7. Rosell R, Carcereny E, Gervais R, Vergnenegre A, Massuti B, Felip E, Palmero R, Garcia-Gomez R, Pallares C, Sanchez JM, Porta R, Cobo M, Garrido P, et al. Erlotinib versus standard chemotherapy as first-line treatment for European patients with advanced EGFR mutation-positive non-small-cell lung cancer (EURTAC): a multicentre, open-label, randomised phase 3 trial. Lancet Oncol. 2012; 13:239-246.

8. Shi Y, Zhang L, Liu X, Zhou C, Zhang L, Zhang S, Wang D, Li Q, Qin S, Hu C, Zhang Y, Chen J, Cheng Y, et al. Icotinib versus gefitinib in previously treated advanced nonsmall-cell lung cancer (ICOGEN): a randomised, doubleblind phase 3 non-inferiority trial. Lancet Oncol. 2013; 14:953-961.

9. Yamamoto H, Toyooka S, Mitsudomi T. Impact of EGFR mutation analysis in non-small cell lung cancer. Lung Cancer. 2009; 63:315-321.

10. NCCN guidelines for non-small cell lung cancer, available at https:/www.nccn.org/store/login/login. aspx?ReturnURL=https://www.nccn.org/professionals/ physician_gls/pdf/nscl.pdf.

11. Overman MJ, Modak J, Kopetz S, Murthy R, Yao JC, Hicks ME, Abbruzzese JL, Tam AL. Use of research biopsies in clinical trials: are risks and benefits adequately discussed? J Clin Oncol. 2013; 31:17-22.

12. Leon SA, Shapiro B, Sklaroff DM, Yaros MJ. Free DNA in the serum of cancer patients and the effect of therapy. Cancer Res. 1977; 37:646-650.

13. Sorber L, Zwaenepoel K, Deschoolmeester V, Van Schil PE, Van Meerbeeck J, Lardon F, Rolfo C, Pauwels P. Circulating cell-free nucleic acids and platelets as a liquid biopsy in the provision of personalized therapy for lung cancer patients. Lung Cancer. 2016. 30312-30319.

14. Pérez-Callejo D, Romero A, Provencio M, Torrente M. Liquid biopsy based biomarkers in non-small cell lung cancer for diagnosis and treatment monitoring. Transl Lung Cancer Res. 2016; 5:455-465.

15. Wang S, Han X, Hu X, Wang X, Zhao L, Tang L, Feng Y, Wu D, Sun Y, Shi Y. Clinical significance of pretreatment plasma biomarkers in advanced non-small cell lung cancer patients. Clin Chim Acta. 2014; 430:63-70.

16. Yung TK, Chan KC, Mok TS, Tong J, To KF, Lo YM. Single-molecule detection of epidermal growth factor receptor mutations in plasma by microfluidics digital PCR in non-small cell lung cancer patients. Clin Cancer Res. 2009; 15:2076-2084.

17. Kimura H, Suminoe M, Kasahara K, Sone T, Araya T, Tamori S, Koizumi F, Nishio K, Miyamoto K, Fujimura M,
Nakao S. Evaluation of epidermal growth factor receptor mutation status in serum DNA as a predictor of response to gefitinib (IRESSA). Br J Cancer. 2007; 97:778-784.

18. Bai H, Mao L, Wang HS, Zhao J, Yang L, An TT, Wang X, Duan CJ, Wu NM, Guo ZQ, Liu YX, Liu HN, Wang YY, et al. Epidermal growth factor receptor mutations in plasma DNA samples predict tumor response in Chinese patients with stages IIIB to IV non-small-cell lung cancer. J Clin Oncol. 2009; 27:2653-2659.

19. Jiang B, Liu F, Yang L, Zhang W, Yuan H, Wang J, Huang G. Serum detection of epidermal growth factor receptor gene mutations using mutant-enriched sequencing in Chinese patients with advanced non-small cell lung cancer. J Int Med Res. 2011; 39:1392-1401.

20. Xu F, Wu J, Xue C, Zhao Y, Jiang W, Lin L, Wu X, Lu Y, Bai H, Xu J, Zhu G, Zhang L. Comparison of different methods for detecting epidermal growth factor receptor mutations in peripheral blood and tumor tissue of non-small cell lung cancer as a predictor of response to gefitinib. Onco Targets Ther. 2012; 5:439-447.

21. Zhang H, Liu D, Li S, Zheng Y, Yang X, Li X, Zhang Q, Qin N, Lu J, Ren-Heidenreich L, Yang H, Wu Y, Zhang X, et al. Comparison of EGFR signaling pathway somatic DNA mutations derived from peripheral blood and corresponding tumor tissue of patients with advanced non-small-cell lung cancer using liquidchip technology. J Mol Diagn. 2013; 15:819-826.

22. Kim ST, Jung HY, Sung JS, Jo UH, Tanaka T, Hagiwara K, Park KH, Shin SW, Kim JS, Kim YH. Can serum be used for analyzing the EGFR mutation status in patients with advanced non-small cell lung cancer? Am J Clin Oncol. 2013; 36:57-63.

23. Li X, Ren R, Ren S, Chen X, Cai W, Zhou F, Zhang Y, Su C, Zhao C, Li J, Cheng N, Zhao M, Zhou C. Peripheral blood for epidermal growth factor receptor mutation detection in non-small cell lung cancer patients. Transl Oncol. 2014; 7:341-348.

24. Douillard JY, Ostoros G, Cobo M, Ciuleanu T, Cole R, McWalter G, Walker J, Dearden S, Webster A, Milenkova T, McCormack R. Gefitinib treatment in EGFR mutated caucasian NSCLC: circulating-free tumor DNA as a surrogate for determination of EGFR status. J Thorac Oncol. 2014; 9:1345-1353.

25. Zhu G, Ye X, Dong Z, Lu YC, Sun Y, Liu Y, McCormack R, Gu Y, Liu X. Highly Sensitive Droplet Digital PCR Method for Detection of EGFR-Activating Mutations in Plasma Cell-Free DNA from Patients with Advanced Non-Small Cell Lung Cancer. J Mol Diagn. 2015; 17:265-272.

26. Mok T, Wu YL, Lee JS, Yu CJ, Sriuranpong V, SandovalTan J, Ladrera G, Thongprasert S, Srimuninnimit V, Liao M, Zhu Y, Zhou C, Fuerte F, et al. Detection and Dynamic Changes of EGFR Mutations from Circulating Tumor DNA as a Predictor of Survival Outcomes in NSCLC 
Patients Treated with First-line Intercalated Erlotinib and Chemotherapy. Clin Cancer Res. 2015; 21:3196-3203.

27. Rachiglio AM, Esposito Abate R, Sacco A, Pasquale R, Fenizia F, Lambiase M, Morabito A, Montanino A, Rocco G, Romano C, Nappi A, Iaffaioli RV, Tatangelo F, et al. Limits and potential of targeted sequencing analysis of liquid biopsy in patients with lung and colon carcinoma. Oncotarget. 2016; 7:66595-66605. https://doi.org/10.18632/ oncotarget.10704.

28. Ma M, Shi C, Qian J, Teng J, Zhong H, Han B. Comparison of plasma and tissue samples in epidermal growth factor receptor mutation by ARMS in advanced non-small cell lung cancer. Gene. 2016; 591:58-64.

29. Chai X, Ren P, Wei B, Ma J, Mai L, Cram DS, Song Y, Guo Y. A comparative study of EGFR oncogenic mutations in matching tissue and plasma samples from patients with advanced non-small cell lung carcinoma. Clin Chim Acta. 2016; 457:106-111.

30. Jaeschke R, Guyatt GH, Sackett DL. Users' guides to the medical literature. III. How to use an article about a diagnostic test. B. What are the results and will they help me in caring for my patients? The Evidence-Based Medicine Working Group. JAMA. 1994; 271:703-707.

31. Jahr S, Hentze H, Englisch S, Hardt D, Fackelmayer FO, Hesch RD, Knippers R. DNA fragments in the blood plasma of cancer patients: quantitations and evidence for their origin from apoptotic and necrotic cells. Cancer Res. 2001; 61:1659-1665.

32. Schwarzenbach H, Hoon DS, Pantel K. Cell-free nucleic acids as biomarkers in cancer patients. Nat Rev Cancer. 2011; 11:426-437.

33. Alix-Panabières C, Schwarzenbach H, Pantel K. Circulating tumor cells and circulating tumor DNA. Annu Rev Med. 2012; 63:199-215.

34. Esteller M, Sanchez-Cespedes M, Rosell R, Sidransky D, Baylin SB, Herman JG. Detection of aberrant promoter hypermethylation of tumor suppressor genes in serum DNA from non-small cell lung cancer patients. Cancer Res. 1999; 59:67-70.

35. Kimura H, Kasahara K, Shibata K, Sone T, Yoshimoto A, Kita T, Ichikawa Y, Waseda Y, Watanabe K, Shiarasaki H, Ishiura Y, Mizuguchi M, Nakatsumi Y, et al. EGFR mutation of tumor and serum in gefitinib-treated patients with chemotherapy-naive non-small cell lung cancer. J Thorac Oncol. 2006; 1:260-267.

36. Kimura H, Kasahara K, Kawaishi M, Kunitoh H, Tamura T, Holloway B, Nishio K. Detection of epidermal growth factor receptor mutations in serum as a predictor of the response to gefitinib in patients with non-small-cell lung cancer. Clin Cancer Res. 2006; 12:3915-3921.

37. Zhao X, Han RB, Zhao J, Wang J, Yang F, Zhong W, Zhang L, Li LY, Wang MZ. Comparison of epidermal growth factor receptor mutation statuses in tissue and plasma in stage I-IV non-small cell lung cancer patients. Respiration. 2013; 85:119-125.
38. Mack PC, Holland WS, Burich RA, Sangha R, Solis LJ, Li Y, Beckett LA, Lara PN Jr, Davies AM, Gandara DR. EGFR mutations detected in plasma are associated with patient outcomes in erlotinib plus docetaxel-treated non-small cell lung cancer. J Thorac Oncol. 2009; 4:1466-1472.

39. Hu C, Liu X, Chen Y, Sun X, Gong Y, Geng M, Bi L. Direct serum and tissue assay for EGFR mutation in non-small cell lung cancer by high-resolution melting analysis. Oncol Rep. 2012; 28:1815-1821.

40. Song GH, Ren J, Zhang LJ, Di LJ, Yuan YH, Yu J, Jia J. Low Correspondence of EGFR Mutations in Tumor Tissue And Paired Serum of Non-Small-Cell Lung Cancer Patient. Chinese Journal of Cancer Research, 2010; 22:27-31.

41. Wu Y, Liu H, Shi X, Song Y. Can EGFR mutations in plasma or serum be predictive markers of non-smallcell lung cancer? A meta-analysis. Lung Cancer. 2015; 88:246-253.

42. Luo J, Shen L, Zheng D. Diagnostic value of circulating free DNA for the detection of EGFR mutation status in NSCLC: a systematic review and meta-analysis. Scientific Reports. 2014; 4:116-120.

43. Mao C, Yuan JQ, Yang ZY, Fu XH, Wu XY, Tang JL. Blood as a substitute for tumor tissue in detecting EGFR mutations for guiding EGFR TKIs treatment of nonsmall cell lung cancer. Medicine. 2015; 94:e775.

44. Costa DB, Kobayashi S, Tenen DG, Huberman MS. Pooled analysis of the prospective trials of gefitinib monotherapy for EGFR-mutant non-small cell lung cancers. Lung Cancer. 2007; 58:95-103.

45. Coghlin CL, Smith LJ, Bakar S, Stewart KN, Devereux GS, Nicolson MC, Kerr KM. Quantitative analysis of tumor in bronchial biopsy specimens. J Thorac Oncol. 2010; 5:448-452.

46. Vallée A, Marcq M, Bizieux A, Kouri CE, Lacroix H, Bennouna J, Douillard JY, Denis MG. Plasma is a better source of tumor-derived circulating cell-free DNA than serum for the detection of EGFR alterations in lung tumor patients. Lung Cancer. 2013; 82:373-374.

47. Rusch VW, Asamura H, Watanabe H, Giroux DJ, RamiPorta R, Goldstraw P. The IASLC lung cancer staging project: a proposal for a new international lymph node map in the forthcoming seventh edition of the TNM classification for lung cancer. J Thorac Oncol. 2009; 4:568-577.

48. Whiting PF, Weswood ME, Rutjes AW, Reitsma JB, Bossuyt PN, Kleijnen J. Evaluation of QUADAS, a tool for the quality assessment of diagnostic accuracy studies. BMC Med Res Methodol. 2006; 6:9.

49. Devillé WL, Buntinx F, Bouter LM, Montori VM, de Vet HC, van der Windt DA, Bezemer PD. Conducting systematic reviews of diagnostic studies: didactic guidelines. BMC Med Res Methodol. 2002; 2:9.

50. Moses LE, Shapiro D, Littenberg B. Combining independent studies of a diagnostic test into a summary 
ROC curve: data-analytic approaches and some additional considerations. Stat Med. 1993; 12:1293-1316.

51. Reitsma JB, Glas AS, Rutjes AW, Scholten RJ, Bossuyt $\mathrm{PM}$, Zwinderman AH. Bivariate analysis of sensitivity and specificity produces informative summary measures in diagnostic reviews.
52. Deeks JJ, Macaskill P, Irwig L. The performance of tests of publication bias andother sample size effects in systematic reviews of diagnostic test accuracy wasassessed. J Clin Epidemiol; 2005; 58:882-93. 